\title{
EFFECT OF Mg (II) METAL ION ON ANTIOXIDANT ACTIVITIES OF ETHANOL EXTRACTS OF RAMBUTAN PEEL (Nephelium lappaceum)
}

\author{
Emmi Astuti ${ }^{* 1}$, Ahyar Ahmad ${ }^{1,2}$, Seniwati Dali ${ }^{1,2}$ \\ ${ }^{1}$ Laboratory of Biochemistry Department of Chemistry, Faculty of Science, University of Hasanuddin \\ ${ }^{2}$ Department of Chemistry, Faculty of Mathematics and Natural Sciences, Hasanuddin University, Jl. \\ Perintis Kemerdekaan Km. 10 Tamalanrea, Makassar, Indonesia 90245 \\ *E-mail: astutiemmi@gmail.com
}

\begin{abstract}
Abstrak. Antosianin adalah salah satu pewarna alami yang banyak digunakan dalam bahan pangan, karena warnanya yang dapat beragam mulai dari merah,biru dan ungu. Penyimpanan antosianin dapat mengakibatkan antosianin terdegradasi, baik adanya interaksi dengan suhu, cahaya, dan oksigen sehingga dapat mempengaruhi stabilitas warna antosianin sendiri, bahkan dapat mengurangi kemampuan antosianin sebagai antioksidan. Permasalahan tersebut dapat diatasi dengan kopigmentasi, yaitu dengan mereaksikan antosianin dengan ion logam. Pada penelitian ini logam yang digunakan adalah $\mathrm{Mg}^{2+}$. Hasil penelitian memperlihatkan bahwa ekstrak etanol kulit buah rambutan diperoleh ekstrak kental sebanyak 23,824 gram dengan kadar total antosianin 709,3866 mg/L dengan aktivitas antioksidan $0,0046 \mu \mathrm{g} / \mathrm{mL}$, ekstrak antosianin dengan penambahan $\mathrm{Mg}^{2+}$ 50, 100 dan 150 ppm memiliki nilai $\mathrm{IC}_{50}$ berturut-turut sebesar 0,0061;0,0048 dan $0,0067 \mu \mathrm{g} / \mathrm{mL}$. Hal ini menunjukkan bahwa penambahan ion logam $\mathrm{Mg}^{2+}$ memperlihatkan perbedaan aktivitas antioksidan antosianin yang tidak signifikan.
\end{abstract}

Kata kunci: antioksidan, antosianin, magnesium, rambutan

\begin{abstract}
Anthocyanin is the one of natural dyes that often used in foodstuffe, because anthocyanin can make a more color like red, blue and purple. Anthocyanin storage can make anthocyanin is damage, because the interaction with tempherature, light, and oxygen show that can given effect about the stability anthocyanin color, and decrease the anthocyanin as an antioxidant. That problem can be solved with copigmentation, that is an anthocyanin reaction with metal ion. In this study can showed that ethanol extract from Rambutan peel and we obtained 23.824 gram with total anthocyanin content of $709.3866 \mathrm{mg} / \mathrm{L}$ with antioxidant activity of 0.0046 $\mu \mathrm{g} / \mathrm{mL}$, and then the extract of anthocyanin with metal ion $\mathrm{Mg}^{2+}$ in concentration 50; 100 and 150 $\mathrm{ppm}$ had $\mathrm{IC}_{50}$ are $0.0061 ; 0.0048$ and $0.0067 \mu \mathrm{g} / \mathrm{mL}$. This conclution from the added of metal ion $\mathrm{Mg}^{2+}$ showed that has not show much different antioxidant activity.
\end{abstract}

Keywords: antioxidant, anthocyanin, magnesium, rambutan. 


\section{INTRODUCTION}

Indonesia is an agribusiness country with the largest income centered on agriculture and plantations with abundant produce. One of them is rambutan fruit, with an average annual production from 2009-2014 of 733,105.5 tons (Ministry of Agriculture, 2015). This plant originated from Indonesia, and began to spread to other tropical countries such as the Philippines and countries in Latin America (Mahisworo et al., 1991).

Rambutan is known to have various pharmacological activities such as antidiabetic, antimicrobial, antihipercholesterol, antioxidant, antihyperuricema, and anticancer (Sadino, 2017). In 2014 Prasetio used rambutan rind as a textile natural dye, because it contained anthocyanin pigments.

According to Francis (1982), anthocyanin is a polar compound, so it can be extracted with polar solvents, such as water, ethanol, and methanol. Solvents that are often used to extract anthocyanins are methanol or ethanol which is acidified with $\mathrm{HCl}$. However, due to the toxic nature of methanol, ethanol is usually used in food systems acidified with $\mathrm{HCl}$. Based on the research conducted by Syarifuddin (2011), Moulana et al. (2012), Hutapea et al. (2014) and Wulandari (2014) good solvents used to extract anthocyanin are ethanol solvents, because the total anthocyanin content produced is greater than that of methanol.

Anthocyanin pigments have biological activities that are beneficial to the health of the body. But along with the length of storage, anthocyanins can experience damage due to environmental influences during storage. One way to overcome this problem is through a process with anthocyanin copigmentation with $\mathrm{Mg}$ (II) metal (Brouillard, 1982).

Kondo et al. (1992) prove that the complex between $\mathrm{Mg} 2+$ and anthocyanin produces a more stable pigment complex. Magnesium ( $\mathrm{Mg}$ ) plays a role in the smooth operation of various enzymes. Magnesium is needed by the body to produce 300 types of enzymes, sending messages through the nervous system, making the muscles stay flexible and relaxed and maintaining bone and tooth strength (Budiasih, 2009).

Based on the description above, further research is needed on the effect of adding metal ions $\mathrm{Mg}$ (II) to the anthocyanin activity of the ethanol extract of rambutan peel.

In this study anthocyanin extraction from rambutan peel using ethanol solvent was extracted, then extracted with $\mathrm{Mg}$ metal and tested for antioxidant activity before and after copigmentation using the DPPH method.

Indonesia merupakan negara agribisnis dengan penghasilan terbesarnya terpusat pada pertanian dan perkebunan dengan hasil buminya yang melimpah. Salah satunya adalah buah rambutan, dengan rata-rata produksi per tahunnya dari 2009-2014 sebanyak 733.105,5 ton (Kementrian Pertanian, 2015). Tanaman ini asli berasal dari Indonesia, dan mulai menyebar ke negara tropis lainnya seperti Filipina dan negara-negara di Amerika Latin (Mahisworo dkk., 1991).

\section{MATERIAL AND METHOD}

This research was carried out by extracting anthocyanin from rambutan 
peel, then characterized by UV-Vis spectrophotometer (spectrum and total anthocyanin content) and Infrared Spectroscopy (functional group analysis), and determining anthocyanin activity by DPPH method.

\section{RESULT AND DISCUSSION}

The crude extract obtained from extracting 120 grams of rambutan fruit skin was 23.824 grams. The extract obtained was analized by a UV-Vis spectrophotometer obtained by the spectrum as shown in Figure 1.

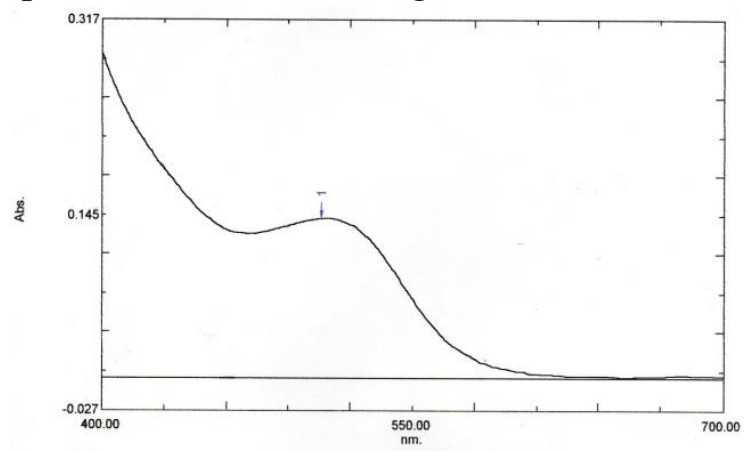

Figure 1. The maximum wavelength ( $\lambda$ maks) of ethanol extract from rambutan fruit skin

The maximum wavelength of ethanol extract of rambutan peel obtained is $506 \mathrm{~nm}$. Harborne (1987), states that the maximum absorbance achieved by anthocyanins is at wavelengths of 490-550 $\mathrm{nm}$. So the results obtained are in accordance with the characteristics of the maximum anthocyanin wavelength and it can be said that rambutan peel extract contains anthocyanin.

Determination of anthocyanin levels was calculated using the $\mathrm{pH}$ difference method at $\mathrm{pH} 1$ and $\mathrm{pH}$ 4.5. Based on the results of the calculation, the total anthocyanin level was $709.3866 \mathrm{mg} /$ L.

$\mathrm{A}=\left(\mathrm{A}_{\lambda \text { maks }}-\mathrm{A}_{700}\right)_{\mathrm{pH} 1}-\left(\mathrm{A}_{\lambda \text { maks }}-\mathrm{A}_{700}\right)_{\mathrm{pH} 4,5}$

$A=(0,142-0,002)-(0,06-0,005)$

$\mathrm{A}=0,085$

Total content of anthocyanin $(\mathrm{mg} / \mathrm{L})$

$$
\begin{aligned}
& =\frac{\mathrm{A} \times \mathrm{BM} \times \mathrm{FP} \times 1000}{\varepsilon \times 1} \\
& =\frac{0,085 \times 449,2 \mathrm{~g} / \mathrm{mol} \times 500 \times 1000}{26900 \mathrm{~L} / \mathrm{mol} . \mathrm{cm} \times 1 \mathrm{~cm}} \\
& =709,3866 \mathrm{mg} / \mathrm{L}
\end{aligned}
$$

Where $\mathrm{BM}=$ molecule mass of cyianidin-3-glucoside $(449,2$ $\mathrm{g} / \mathrm{mol}$ )

$\mathrm{DF}=$ dilution factor

e $=$ absorptivity molar cyanidin-3- glucoside (26.900 L/mol.cm)

$\mathrm{L}=$ cuvette thick $(1 \mathrm{~cm})$

Analysis with infrared spectroscopy obtained the spectrum and wavelength before and after the addition of metal ion $\mathrm{Mg}^{2+}$ can be seen in Figure 2 . 


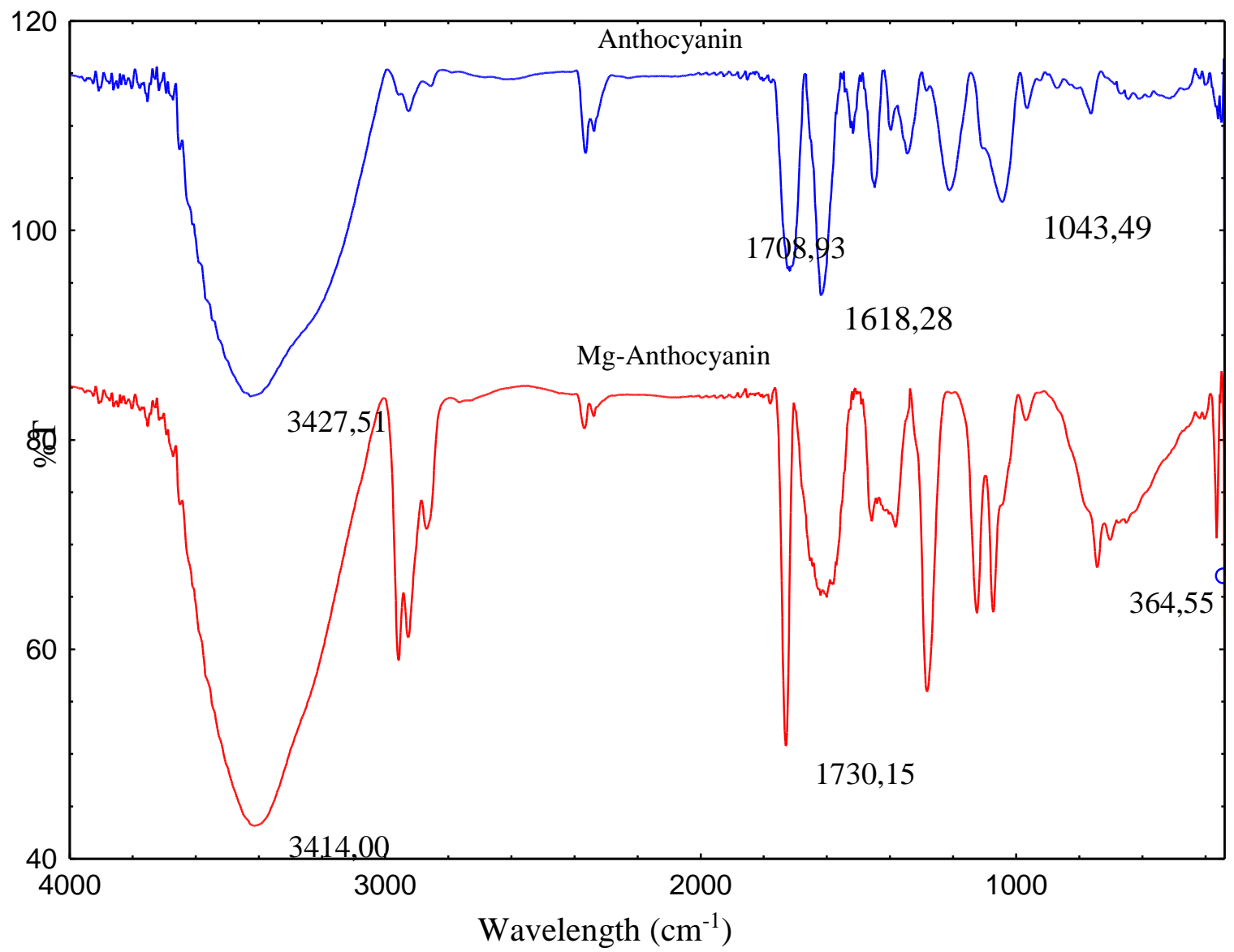

Figure 2. IR spectrum of anthocyanin extract before and after addition of metal (Kopigmentation)

The results of the FTIR spectrum (Figure 2) show a sharp uptake in the wave number area $3427.51 \mathrm{~cm}-1$ which indicates the presence of the $-\mathrm{OH}$ functional group supported by the appearance of absorption in the wave number region $1043.49 \mathrm{~cm}-1$ for the C$\mathrm{O}$ alcohol functional group. Wave numbers also appear with values of $1618.28 \mathrm{~cm}-1$ and $1517.98 \mathrm{~cm}-1$ with sharp absorption, which indicates the presence of a functional group $\mathrm{C}=\mathrm{C}$ aromatic which is reinforced by absorption at a wave number $763.81 \mathrm{~cm}$ 1 for bond absorption $\mathrm{CH}$ aromatic and the absorption of $\mathrm{C}=\mathrm{O}$ bonds is shown at wave number $1708.93 \mathrm{~cm}-1$.
Based on FTIR analysis of the rambutan anthocyanin extract before and after the addition of metals showed that there were changes in wave numbers especially in $\mathrm{OH}$ groups with wave number values before the addition of metal ions of $3427.51 \mathrm{~cm}-1$ and after the addition of ions metal $\mathrm{Mg} 2+$ changed to wave number $3414.00 \mathrm{~cm}-1$.

The shift in wave number indicates that a metal ion binding process occurs with rambutan anthocyanin extract. This is in accordance with the statement of Miguel (2011), that anthocyanins and metals can be bound to hydroxyl groups. 


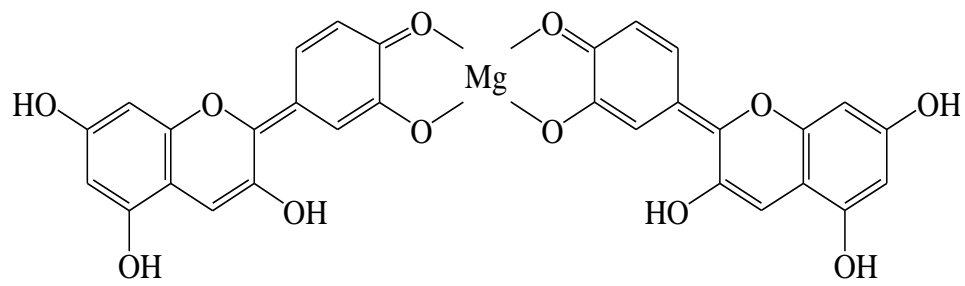

Figure 3. Estimated structure of metal complexes with anthocyanins (Ahmed et al., 2013).

Besides the wave number at $364.55 \mathrm{~cm}-1$, the addition of metal ion $\mathrm{Mg}^{2+}$, shows the M-O bond, indicating the formation of the Mg-Anthocyanin complex (Ahmed and BenGuzzi, 2008).

The results of the analysis of the antioxidant activity test using the DPPH method, the absorbance of extracts and DPPH were measured by a spectrophotometer at the $515 \mathrm{~nm}$ wave length. Measurement of anthocyanin antioxidant activity with Vitamin $\mathrm{C}$ as a comparison can be seen in Table 1.

Table 1. IC50 values and the level of antioxidant strength of ethanolic extract of rambutan fruit skin and Mg-anthocyanin extract and comparison (Positive Control)

\begin{tabular}{ccc}
\hline $\begin{array}{c}\text { Sample/ } \\
\text { comparison }\end{array}$ & IC50 & Intensity \\
\hline $\begin{array}{c}\text { Anthocyanin } \\
\text { Mg-Anthocyanin } \\
50 \text { ppm }\end{array}$ & $0,0046 \mu \mathrm{g} / \mathrm{mL}$ & Very Strong \\
$\begin{array}{c}\mathrm{Mg} \text {-Anthocyanin } \\
100 \mathrm{ppm}\end{array}$ & $0,0061 \mu \mathrm{g} / \mathrm{mL}$ & Very Strong \\
$\mathrm{Mg}$ - Anthocyanin & $0,0048 \mu \mathrm{g} / \mathrm{mL}$ & Very Strong \\
150 ppm & $0,0067 \mu \mathrm{g} / \mathrm{mL}$ & Very Strong \\
\hline & Comparison (Positive Control) & \\
\hline Ascorbic Acid & $0,2349 \mu \mathrm{g} / \mathrm{mL}$ & Very Strong \\
\hline
\end{tabular}

From these data it can be concluded that the anthocyanin of rambutan peels has a stronger antioxidant activity than the positive control of ascorbic acid. IC50 value of rambutan skin extract was obtained $0.0046 \mu \mathrm{g} / \mathrm{mL}$, the most powerful IC50 $\mathrm{Mg}$-anthocyanin value was $100 \mathrm{ppm}$. These results are obtained based on linear regression calculations from the absorbance curve of the sample. Based on Table 1, it can be seen that anthocyanin without the addition of metals compared to the addition of metal ions $\mathrm{Mg} 2+$ has antioxidant activity that is not significantly different. This is due to the addition of metals making anthocyanins more stable, stable compounds are increasingly difficult to react with other compounds (Takeda et al., (1994); Kondo et al. (1992). 


\section{CONCLUSION}

Based on the results of the research conducted, it was shown that the addition of metal ions $\mathrm{Mg}$ (II) showed insignificant differences in anthocyanin antioxidant activity.

\section{REFERENCES}

Ahmed, J. K., Salih, H. A. M., and Hadi. H., 2013, Anthocyanins in Red Beet Juice Act as Scavengers for Heavy Metals Ions as Leed and Cadmium, International Journal of Scince and Technology, 2 (3): 256-274.

Ahmed, A. A., and BenGuzzi, S. A., 2008, Synthesis and Characterization of Some Complexes of Schif Base Derived from Benzidine and Acetylacetone, Journal of Scince and Its Application, 2 (1): 83-90.

Brouillard, R., 1982, Chemical structure of anthrocyanins. Academic Press, London, p. 37-39.

Budiasih, S. K., 2009, Bioanorganic Study: Runutan Minerals in Body Metabolism, Paper presented in the Proceedings of the National Seminar on Research, Education and Application of Mathematics and Natural Sciences, Yogyakarta State University, Yogyakarta.

Francis, F.J., 1982, Analysis of Anthocyanins, Academik Press, New York.

Hutapea, E. R. F., Siahaan, L. O., and Tambun, R., 2014, Anthocyanin Pigment Extraction from Kulit Rambutan (Nephelium lappaceum) with Methanol Solvents, USU Chemical Engineering Journal, 3 (2): 34-40.

Ministry of Agriculture, 2015, Horticulture Production Statistics in 2014, Directorate General of Horticulture, Jakarta.
Kondo, T., Yoshida, K., Nakagawa, A., Kawai, T., Tamura, H., and Goto, T., 1992, Structural bases of blue color development in flower petals from Commelina communis, Journal Nature, 358: 515-518.

Mahisworo, Kusno. S., and Agustinus A., 1991, Bertanam Rambutan, Penebar Swadaya, Jakarta.

Prasetio, D., 2014, Study of the Use of Rambutan Fruit Skin (Naphelium lappaceum, Liin) as Textile Natural Dyes, Unpublished Description, Faculty of Science and Technology, Chemistry Study Program, Sunan Kalijaga State Islamic University, Yogyakarta.

Takeda, K., Yanagisawa, M., Kifune, T., Kinoshita, T., \& Timberlake, C. F., 1994, A blue pigment complex in flowers of Salvia patens, Phytochemistry Journal, 35: 11671169.

Miguel, M.G. 2011, Anthocyanins: Antioxidants and / or antiinflammatory activities, Journal of Applied Pharmaceutical Science, 1 (6): 07-15.

Moulana, R., Juanda, Syarifah, R., and Ria, R., 2012, Effectiveness of Use of Solvents and Acids in the Anthocyanin Pigment Extraction Process of Rosella Flower Petals (Hibiscus sabradiffa L), Indonesian Agricultural Industry Technology Journal, 4 (3) : 20-25.

Sadino, A., 2017, Review: Pharmacological Activities, Active Compounds and Mechanisms of Working of Rambutan (Nephelium lappaceum L.), Farmaka Journal, 15 (3): $16-25$.

Syarifuddin, M. U., 2011, Antioxidant Capacity and Stability of Anthocyanin Extract of Black Gude Peanut Skin (Cajanus cajan Linn) with Solvent Variations, Unpublished Thesis, Agricultural 
Technology Department, Faculty of Agriculture, Sebelas Maret University, Surakarta.

Wulandari, L., 2014, Isolation of Anthocyanin Compounds from Red Rose Flowers (Rosa hybrida I Hort) as Sensitizer on Pyranized Solar Cell (DSSC, unpublished Thesis, Department of Chemistry, Faculty of Mathematics and Natural Sciences, Sebelas Maret University, Surakarta. 